\title{
Vaporous circumambience: Towards an architectonics of atmosphere
}

Michael Tawa

\section{Atmosphere}

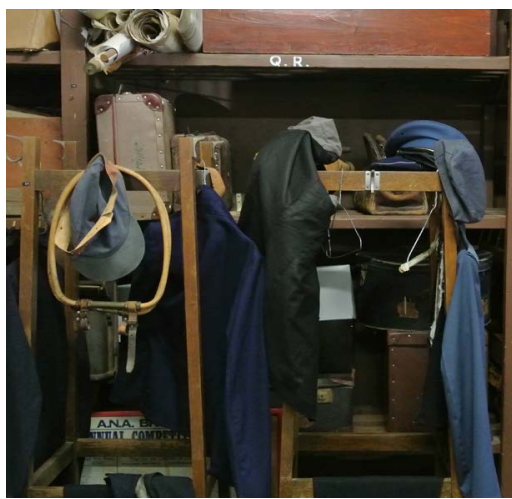

Fig. 1 Things. [Photo: Author, 2013]

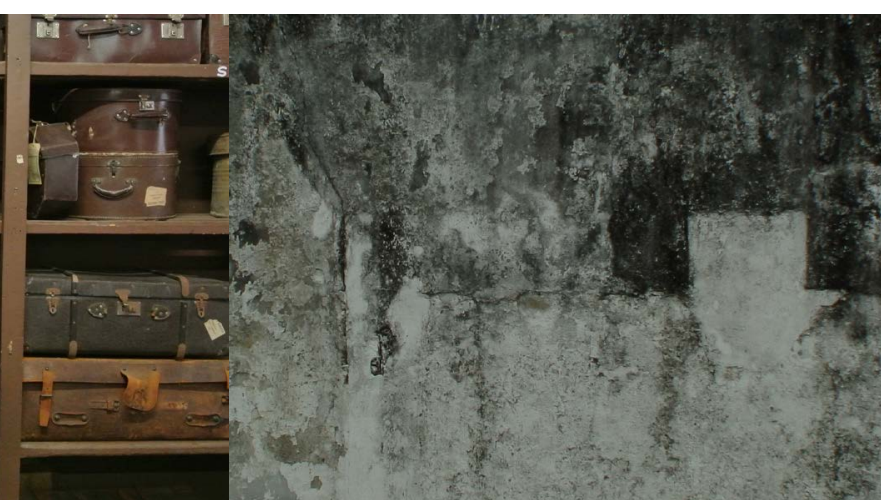

Fig. 2 Maldives. [Photo: Author, 2008]

Tone and emanation - in my terminology, ekstases - determine the atmosphere radiated by things. They are therefore the way in which things are felt to be present in space. This gives us a further definition of atmosphere: it is the felt presence of something or someone in space. For this the ancients had the beautiful expression parousia. Thus, for Aristotle, light is the parousia of fire. (Böhme 2008)

The word atmosphere is from Latin atmosphaera and Greek atmos, meaning vapour or steam and sphaira, meaning sphere. The etymon of atmos implies a sense of blowing, inspiring, arousing: hence of breath or spirit. Yet, curiously, the words vapour, quell and kill are cognate; consider for example Old English cwealm, meaning murder or agonising death. The vaporous is clearly equivocal. It can equally mobilise the nefarious and constitute a threat; hence the well-known alliance between the vaporous and the miasmic, together with its important role in processes of erasure and 'disinfection' that characterise the origins of the modern city.

Gernot Böhme reads atmosphere as the palpable manifestation of a medium, milieu or situation (2010: 27) - as when rays of sunlight enable us to perceive dust-laden air. In architecture, it might be the 'emotional tinge' or 'tuning' of a space. Tinge and tincture are chromatic aspects, a matter of colouring, and hence of calor - of heat and calories. Colour is the outward sign of an inner constitution that surfaces and shows itself. Tinge and tincture can also be a matter of tuning and tone; in other words, of alignment and resonance. Here, sound parallels colour in bringing an inner constitution into audibility; in making it possible for us to 'hear' it. Likewise Stimmung (mood or attunement) is not a subjective colouring applied onto an objective world. We are always 'in' a mood as in a particular countenance or disposition that represents a distinctive co-embeddedness and manner of belonging to the world. As Heidegger noted, mood "comes neither from 'outside' nor from 'inside', but arises out of Being-in-the-world, as a way of such being” (1962: 176). 
The chromatic reference is revealing. Colour originally meant complexion or appearance; yet, again curiously, the etymon of the word, *KEL, to conceal, gives Latin colos, a covering or veil and celare, which means to hide. Consider the word's various cognates: cell, clam, helmet, caldron, hall, shell, cellar, hole, hell. Complexion is a condition of revealing and concealing; or of simultaneously revealing and concealing, presenting and absenting. To cover is to dress-up, to invest - hence to initiate, install, establish or name. It is a key term in the motifs of decoration and ornament, which are in a sense the 'complexion' of the decorated thing or being. The word complexion is itself revealing; the literal meaning being entwined-together, or complicated, through the etymon *PLEK, to plait, braid, weave, ply, fold. Latin complexus, complectere means to embrace, encompass, surround. Complexion is a sign of the complex intricacies of a being as they present themselves to view. Chromatic is from Greek khróma, meaning surface of the body, skin, colour of the skin; a term also used to mean ornaments, embellishments, and which relates to khrós, surface of the body, skin, and khrózein, to touch the surface of the body, to tinge, to colour. Here, the etymon is *GHREU, meaning to rub or grind, probably from the sense of obtaining pigment by grinding ochre. More significant is the reference to touch, which connects tinge and tincture to tact, and thus to an entire ethics if not tactics or techne of the surface. Greek taktike techne, the art of arrangement, is from the etymon *TAG, meaning to touch, handle, set aright; Latin tactus, tangere, mean touch, feel or handle, and techne means the art or skill of weaving, webbing, fabricating or carpentry (texture, text, textile) - in each case the pivotal sense is articulating, joining or connecting parts into an assemblage that is complex and that radiates its complexity as complexion, colour and atmosphere. Yet this touching is tangential. It is a tactility that defers intersection, com-penetration or commixture. It is a matter of percussion, of the com-pressure of air that affects without violating any intervening boundary. What emanates compresses its circumambient environment. That is how we see it, as an alteration in the density, weave, texture or tincture of the milieu. That is also what makes it touching and affective. To be touched is to experience the compressive circumradiance of another being.

What can we usefully make out of these multiple semantic resonances? First, they produce an intentionally unforeclosed inventory functioning as a precise and allusive framework. Second, together they produce an ambiance, atmosphere or complexion of sense. Third, they do so because of their being multiple and discrete, yet consilient; sense emerges out of the circulation of discrete senses, out of a kind of wavering ambit that condenses meaning into a gossamer mist. Fourth, a keynote nevertheless emerges; something firm yet provisional and transitional: that atmosphere is a matter of complexion, colour and tincture; that tincture reveals as it conceals; that the tinge of something or someone or some place is an emergent phenomenon or ekstasis rendering its boundaries indeterminate; that this indeterminacy is produced by multiple senses or systems coexisting without fusing; that this coexistence manifests as a kind of shimmering surfacing or surfactance, ornamenting and embellishing; that the shimmering is also chimerical, evanescent, impermanent - or rather, that it has its own wavering temporality and dilated or aerated spatiality; finally, that this aerated circumambience is the fundamental structure of atmosphere.

\section{Ambiance}

It is observed in the solar eclipses, that there is sometimes a great trepidation about the body of the moon, from which we may likewise argue an atmosphaera, since we cannot well conceive what so probable a cause there should be of such an appearance as this ... that the sun-beams were broken and refracted by the vapors that encompassed the moon. (Wilkins 1638 in Harper 2001-2014)

A key theme in the words ambiance and ambiguity is the sense of going-around, a shifting double-meaning, or, literally, being-driven-to-wander. The ambit that connects ambiance and ambiguity to the equivocal also connects it to the metaphorical and the analogical, which are not 
merely tropes of language but fundamental, constitutive tactics. As Mary Hesse has observed in relation to Aristotle's treatment of analogy, "in a sense all discourse is metaphorical ... all predication is analogical" (Hesse 1965: 338). Metaphor enables language to be transactional. The different senses that wander within the ambit of a world defer to others to produce webs of interrelated, circumstantial meanings. These interrelations are the discrete, aerated texture of atmosphere. They take place in the gaps and interstices of meaning - through the circulations and circuits of sense that cross those gaps, rather than on any fixed terminology or definition that a particular word 'has'. Sense is not a matter of possession but of sharing. Words and ideas 'make' sense by producing meanings out of the resonances they mobilise in relation to other words and ideas. If we say that, in architecture, atmosphere is a metaphor, this is not to devalue or dismiss the concept, but rather to say that it makes no sense apart from the circuits of sense that circulate through it.

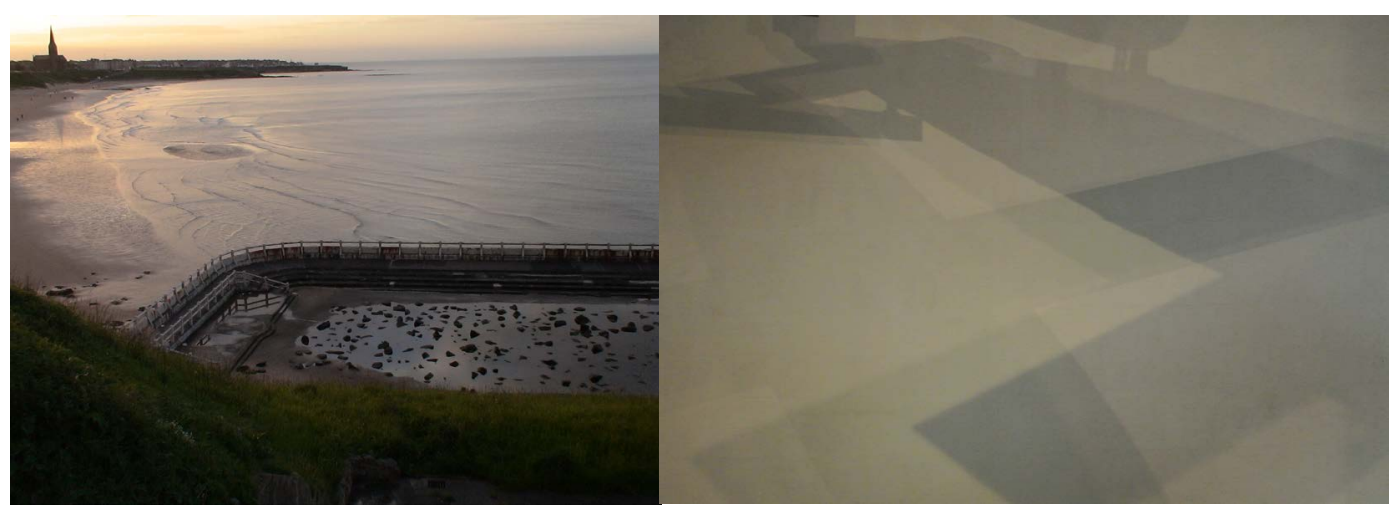

Fig. 3 Cullercoats. [Photo: Author, 2007]

Fig. 4 Wall. [Photo: Author, 1994]

One such ambit, world or whorl of sense is implied by a word often associated with ambiance, the aura. Like atmosphere, the aura is related to the anima - the spirit or breath of a being; an aerial emanation that lifts or rises around it; the characteristic impression or mark of its bearing, its mien. Walter Benjamin famously described the aura as what pertains to originary being, but which can no longer hold in the "age of its mechanical reproducibility". The aura is a mark of its "presence in time and space", a measure of authenticity; while its absence or "liquidation" in the reproductions, images, avatars and simulants that follow are a mark of inauthentic, counterfeit being (Benjamin 1992: 214-215). Hence the aura is the ekstasis of a being, setting or arrangement; such as the complexion of a face, the demeanour of a person or the aspect of a place. This "out-standing" quality evokes the concept of the halo: the eminence and emanation of someone, something or somewhere that is its spatialised and temporalised "being-there" - what Giorgio Agamben called "the imperceptible trembling of the finite that makes its limits indeterminate" (1993: 56).

The etymology of the word halo derives from the Greek word for salt, halos - in the sense of hyloclasty, or salt crystallisation. The halo is the nimbus or aureole of icon painting; but it can also refer to other phenomena, more or less sublime, more or less nebulous - for example the Platonic Music of the Spheres, which is the audible sound produced by the 'mechanism' that keeps the cosmos on track: that is, the perceptible correlate of an imperceptible order or the ubiquitous hum of unidentifiable servicing machinery in office buildings. Both are emergent crystallisations of sorts, both produce halos, both produce atmosphere.

These readings of aura and halo imply that atmosphere is not something that skins or hovers, detached, around and outside a being. Rather, they are the evidence and announcement of a being's internal order or arrangement, its constitutive complexities - in short, its taxis: again a matter of touch, tact and ethos. The countenance and look, or the gaze of a being (not only what it looks like 
how it looks), convey something fundamental about the person or the place. How we look (whether we calculatedly lock and violate or incarcerate the looked-at; whether we look-after or look-out-for it; whether we look with kind regard, with an eye to solicitude and care) can debilitate or enable, destroy or create. The look of a being, its appearance, is the aura that forefronts it, that brings it into view; but it is also a sphere of influence, with affective powers that can induce change.

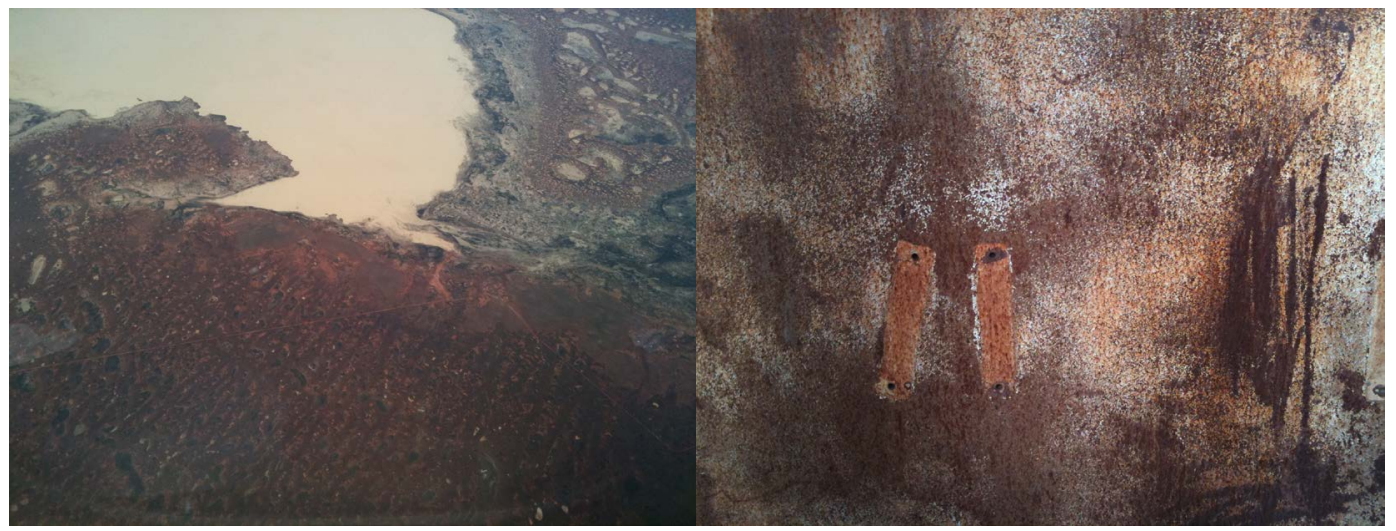

\section{Porosity}

Cities are enormous madrepore in whose tangle, and in the midst of whose concrete or chalky matter, there will never pass enough passages and bridges and canals and ventilating chimneys and flowing spaces and interstices and clearings. (Gaudin 1992: 122)
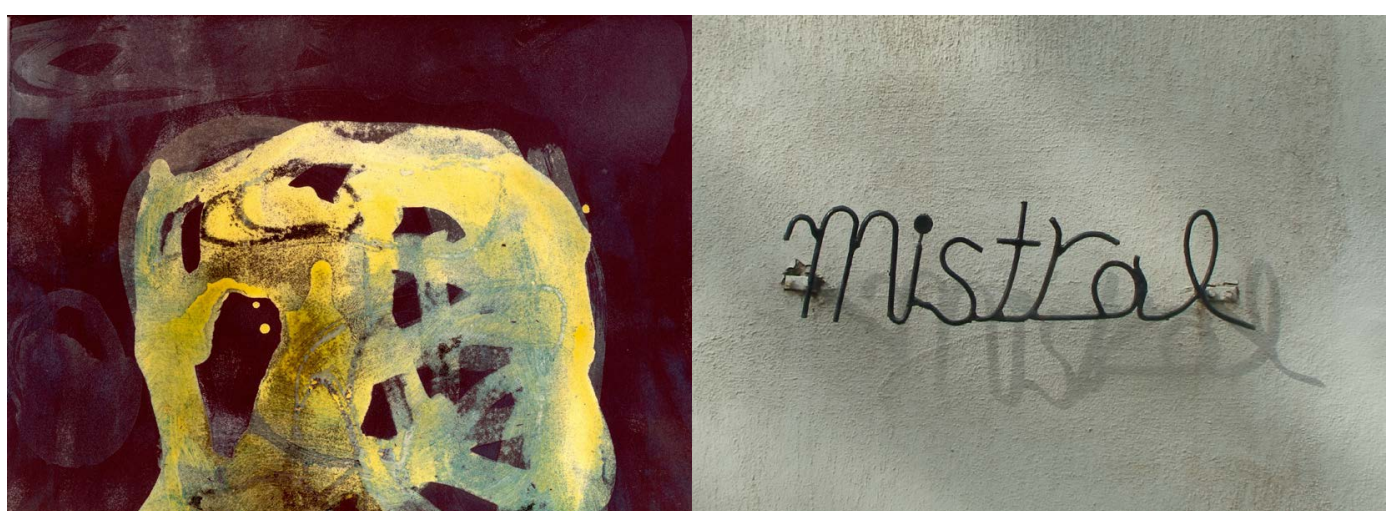

Fig. 7 Head. [Drawing: Author, 2010]

Fig. 8 Cyprus. [Photo: Author, 2009]

If, as etymology suggests, atmosphere is vaporous circumambience, it might be something like the mist that renders a landscape indistinct, permeating and liberating form by rendering its contours indeterminate and immanent (Jullien 2009: 129); or else a sphere of arousal, the "great trepidation" or haze that blurs the moon's outline and marks its advent as emergent radiance or parousia (Wilkins 1638). Greek parousia derives from from para- and Indo-Germanic prea, meaning through or forward-from-close-beside and ousia, meaning advent, arrival, presence, being, essence. Parousia is therefore "anticipated prospect of arrival", or "immanent presence", 
but also and is antithetical to the aporetic condition or impasse where we find ourselves "without-passage". Between potentiality and actuality, the material and the immaterial, one idea and another, existence is always through something that resists and prohibits; it is always a trajection of some kind, a perforation of some boundary plus the material obduracy of that boundary. There must therefore be a sort of porous, aerated, permeable materiality to the structure of atmosphere: a distributed network of hollows, a disparate consistency made of gaps which never close up or fuse into a unity. Like the vaporous fog that dissimulates everything into an undifferentiated matrix, atmosphere maintains everything in a suspended state of potential, keeping it always provisional and on the verge of arriving.

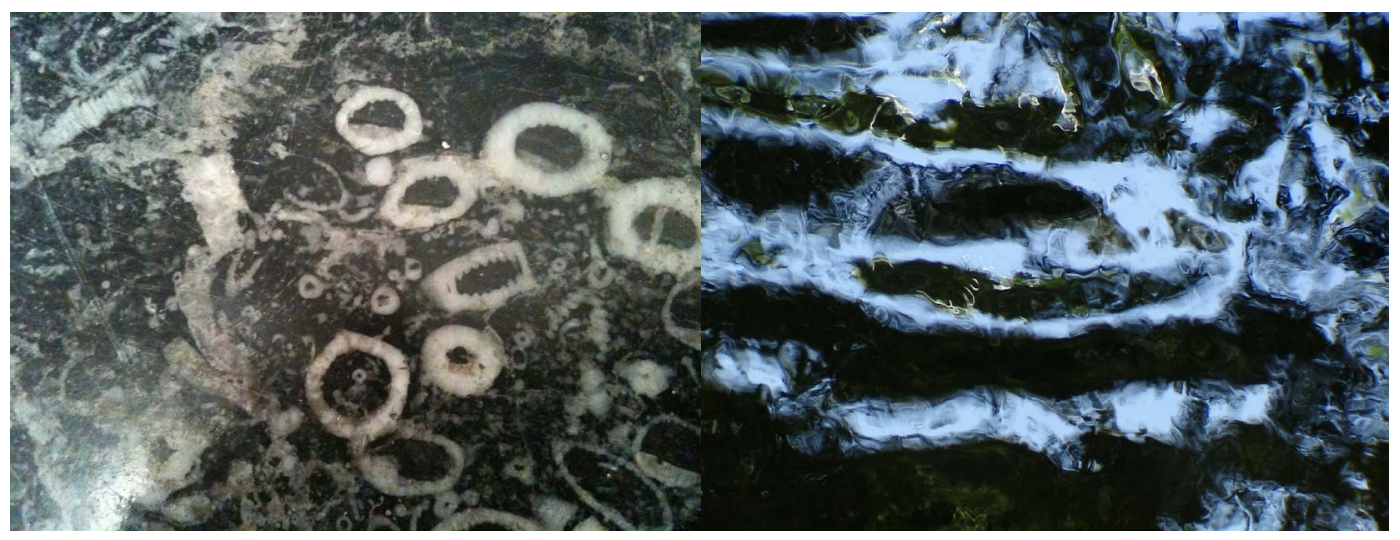

Fig. 9 Remains. [Photo: Author, 2012]

Fig. 10 Interval. [Photo: Author, 2000]

Interstice, interval, milieu - these constitute a surrounding or medium; a mathematical mean, a tectonic intermittence and an ethical mediality, mediatedness or mediance (Berque 1990): that is, a way of being-with-our-self, with-others and with-the-world. This is Heidegger's Mitsein - the authentic manner of being-there-in-the-world as encounter, necessitating attentiveness towards things and others that is characterised by care (Sorgen), concern (Besorgen) and solicitude (Fürsorge). As Bernard Stiegler notes, "the self is indissociable from care (soin) in as much it has a double dimension that is psychic and social, so that to take care of oneself is always already to take care of the other and of others" (2008: 283). The solicitude which characterises care is caring-for in the sense of having regard for the welfare of the other, to liberate and make room for them to be there also (Heidegger 1962: 158-9); to solicit out of potentiality and thus enable something, someone or some ones to emerge and surge-forth-into-presence. The topography of the porous, the interstitial and the inter-ludic must be resolutely ethical.

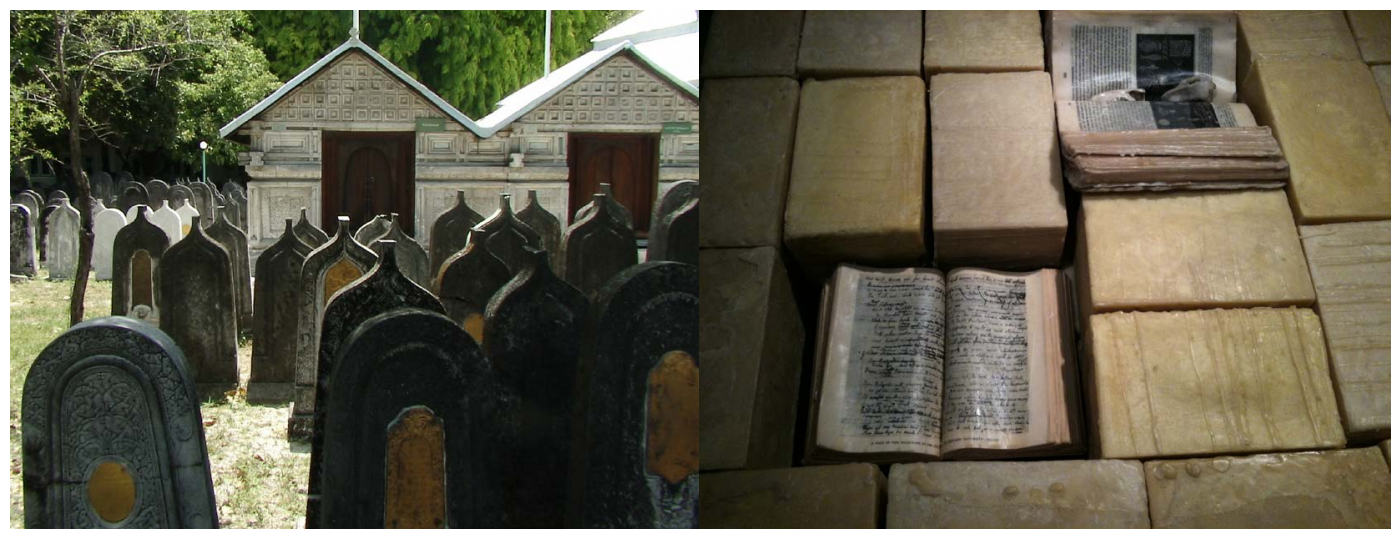

Fig. 11 Maldives. [Photo: Author, 2008]

Fig. 12 Pip Stokes-Burgess (1951-2011). A shrine for Orpheus. [Photo: Author, 2010] 


\section{Conjugation}

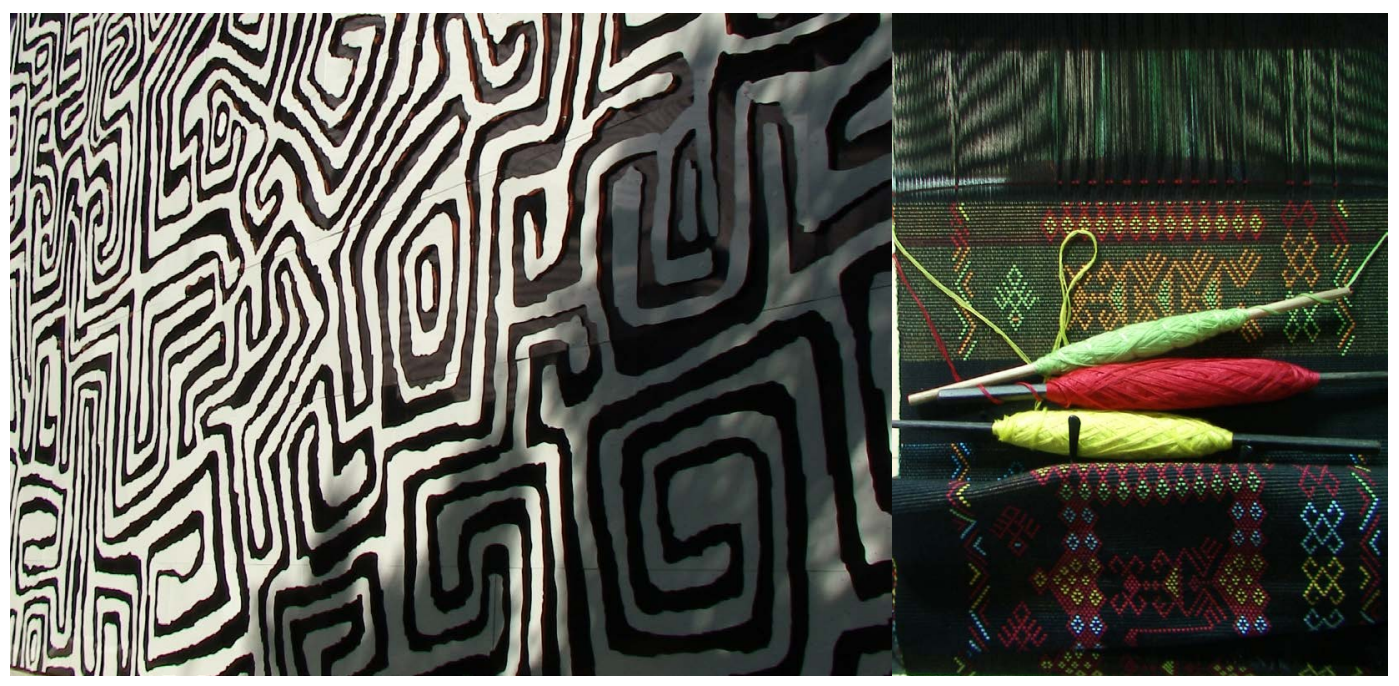

Fig. 13 Jackie Kultjunyintja Giles Tjapaltjarri with Cracknell \& Lonergan Archi- $\quad$ Fig. 14 Hainan. [Photo: Author, 2009] tects (2009). Jjamu Tjamu, public artwork, Fox Studios. [Photo: Author, 2010]

There is another sense in which the interstitial and porosity are important for atmosphere. Such a sense hinges on the necessary structural condition of unaligned multiplicity - that is, an ordering system of multiple, coexistent components that resonate without fusion, that defer one to the other without ever being resolved into a singularity. Such a system might be semantic and consist of multiple coexistent meanings that produce consilience between them while remaining separate; or it might consist of multiple spatial or geometric systems overlaid within a single building but without coinciding. In such cases the resultant order remains discrepant and incommensurable - that is, it maintains porosity. Yet, in their interstices, the concatenation or conjugation of these systems within the assemblage begins to produce emergent conditions that were not present in any of its component parts (Delanda 2006: 2012).

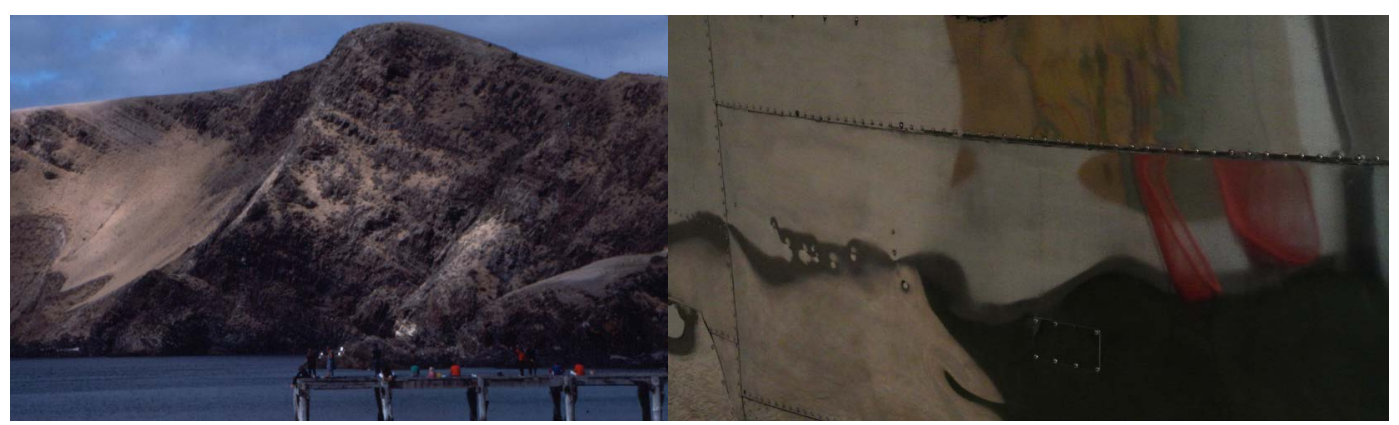

Fig. 15 South Australia. [Photo: Author, 1994]

Fig. 16 Dissimulation. [Photo: Author, 2013]

Not knowing the way out or the way in, wonder dwells in a between, between the most usual, beings, and their unusualness, their 'is.' It is wonder that first liberates this between as the between and separates it out. Wonder - understood transitively - brings forth the showing of what is most usual in its unusualness. Not knowing the way out or the way in, between the usual and the unusual, is not helplessness, for wonder as such does not desire help but instead precisely opens up this between, which is impervious to any entrance or escape, and must constantly occupy it. (Heidegger 1994: 145) 
The interstitial is a necessary condition of otherness and multiplicity. The discontinuities it makes possible by keeping things disseveral are also the potentialities it enables and the capacities it preserves for an interminable process of negotiation, interpretation and reconstitution. The interval makes possible many things. It makes place possible: this space apart from/as well as/and that space, one time rather than/as well as/and another time, this sense apart from/as well as/and that sense. Multiple epistemological registers, multiple sedimentations of meaning, multiple narrative lines, multiple arenas of operation, multiple scales of affect, multiple networks of relay, multiple dimensions of a being, multiple transactions of solicitude. The excess delivered by these kinds of epistemological, operational, spatiotemporal and architectonic transactions manifests as surfactant circumambiance and atmosphere.

The final sequence in Paolo and Vittorio Taviani’s film Kaos (1984) recounts the narrator's conversation with (the ghost of) his mother, in which she recounts an event in her youth. Fleeing Sicily in a precarious skiff, the family stops at the island of Lipari to rest. On the beach the children head for the high pumice cliffs that back the sea. She is older and has to remain with her ailing mother. Seeing her sadness, the mother eventually signals for her to join her siblings. They climb to the top of the blinding white cliffs and, filmed by a rear shot taken diagonally down to the azure sea that excludes the horizon line, they slowly sidestep and dance down the pumice slopes, eventually merging with the ocean. The soundtrack to this extraordinary scene is Barbarina's aria L'ho perduta, me meschina from Mozart's The Marriage of Figaro.

What is the aura, ambiance or atmosphere of this scene? How is it produced? Without de-vivifying the scene by anatomising and inventorying its multiple sense-complexes, how might we broach an understanding of what it is exactly that produces such an atmosphere? How might we more precisely theorise it, in the proper sense of seeing it or being captivated by its extantness - what Heidegger called the being perceived of the perceived, its perceivedness (1982: 48). The atmosphere of the sequence results from several discrete but coincident conditions inherent within the cinematic setup. First, the narrator, the author Luigi Pirandello upon whose short stories the film is based, visits his empty family home after his mother has passed away. He remembers a story that his mother used to tell him when he was young. He is in a reverie of recollection, tracing evanescent memories, making sense of who he is. The film then shifts to that earlier time and the narrative voice becomes that of the mother. There are several overlapped stories and voices - the narrator's journey into the past, Pirandello's stories, the narrator's mother in her penultimate years, the same woman as a young girl at the pumice beach. And then there is the Mozart aria. L'ho perduta, me meschina means "Woe is me, I have lost it. ${ }^{2}$ The libretto refers to a brooch that the peasant girl Barbarina was to give to the countess' maid but which she has lost. A trifling moment in the scheme of things, sung by a minor character, but which Mozart scores to produce extraordinary emotional intensity. How is this achieved? ${ }^{3}$

The affective quality of the music could be ascribed to its being set in the minor mode (F minor). The key of F minor has four flats, and flat keys were often associated with grief and dejection in the vocabulary of the time. The presence of diminished 7th chords and three-note figures produce sharp dissonances, also associated with grief and sadness; while the use of chromatic chords (which include notes extraneous to the mode or key of the piece, hence producing an "alien" or "deviant" presence) add harmonic complexity or 'colour'. The vocal line is fragmented, with short sighing gestures set against the persistent quaver figures of the accompaniment that together convey a sense of bewilderment and powerlessness. Contributing to the quality of unfulfilled and perhaps unfulfillable desire is the dissonance at the first "me-SCHI- $n a$ ": the resolution at "-na" being only partial and the resulting chord being unstable according to the norms of tonality. In fact, the piece never comes properly to an end because of Figaro's interruption. At one level, there is a disparity between Barbarina's trifling distress and the deep scale of sadness in the music. At another, the dissonant (or internally disparate) modality of the music accentuates the emotional tension in the filmic narrative, contributing a great deal to its Stimmung. This modal disparity is at odds with the sublimely enveloping imaging of the landscape and the eventual absorption of the children's joyful abandon 
into its azure field. Because of such dissonances, Mozart's score and the Tavianis' scene achieve musical and cinematic expressions of an archetypal motif: the impossibility of fulfilling desire. As Deleuze and Parnet noted (2004: 'désir'; see also 1996: 8-15), we never desire one thing (a person, a coat, a fragrance), we always desire an assemblage, a complexion or inter-folding of multiple conditions (a person + a coat + a fragrance); we always desire a milieu, a world - that is, an ambiance. In the film's exquisite conjunction of narrative, image and sound these disparities parallel the narrator's desire to recollect his past, his desire for the mother and her youth, the mother's desire to relive and retell the story, the child's desire to join her siblings, the desire of the children's falling and mergence with the sea, and an overarching and tragic desire for surrender and release - a veritable "authentic being-towards-death" (Heidegger 1962: 255) that is constitutive of ex-static being-in-the-world.

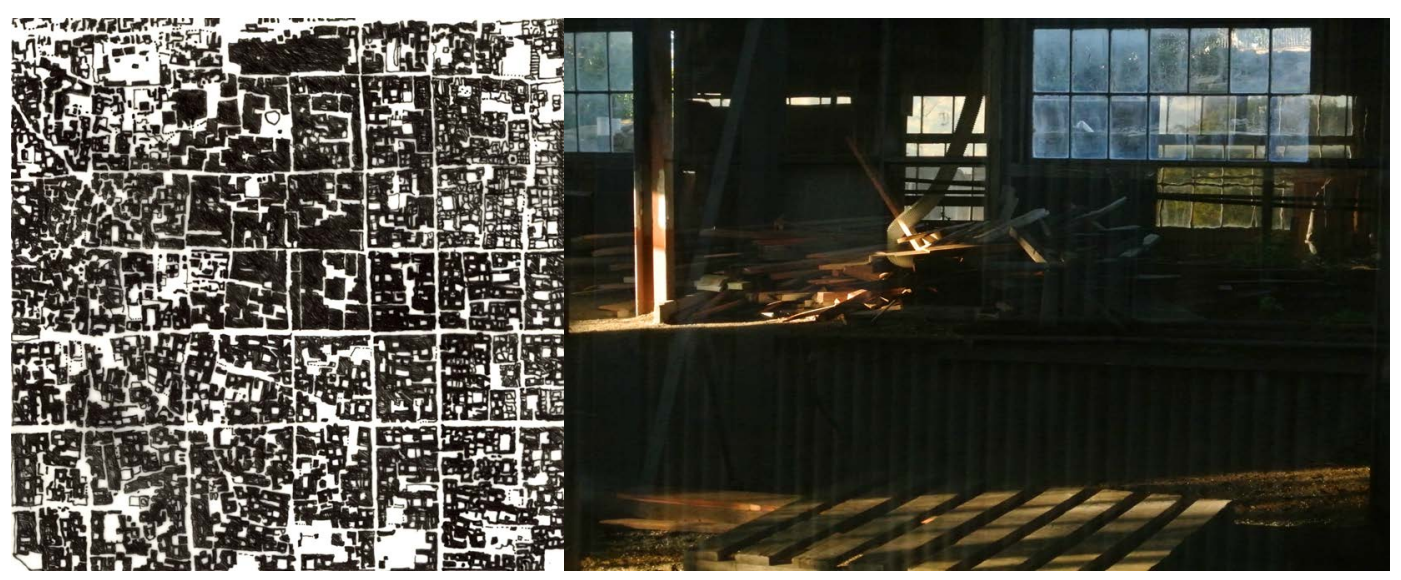

Fig. 17 Plan of Jaipur. [Drawing: Author, 2007]

Fig. 18 Cockatoo Island. [Photo: Author, 2013]

In parallel ways, architecture has the capacity to set up productive conditions based on incommensurable, discrepant assemblages. This is possible across several registers. One is the underlying spatial or geometric system that directs relative arrangement, scale, proportion, symmetry, rhythm, patterns and shapes. Another is the material and tectonic system of connections and joints that regulate the formal, volumetric and technical assemblage of parts. A further register relates to the spatial sequences, narratives and experiences that are enabled through the spatial and tectonic setup. There is also a semantic register through which architecture engages metaphorical or symbolic referents, thus relating built form, spatiality and temporality to broader conditions and currents of human knowledge and experience - metaphysical, philosophical, religious, ethical, political, social, scientific and aesthetic among others. The degree to which these different registers are aligned, coordinated and resolved within a single work contributes substantially to its character and complexion. Where different registers and references are mobilised to circulate and wander, the texture of the work will trigger an on-going process of curiosity, inquiry and discovery that seeks to understand and relate them to each other, to see how they connect and fit together across the gaps and discontinuities established between them. Consequently a work will always produce unexpected resonances, open up new readings and generate new patterns of meaning. Conversely, the more resolved and integrated the various registers are, the more stable and singular will be a work's meaning, the less open it will be to discovery and wonder. My contention here is that atmosphere is driven and produced precisely by the kinds of discrepancies and incommensurabilities that keep meaning virtual, provisional and in a state of unactualised potential.

I have written elsewhere on the circulation of referents and metaphors in architecture - for example, the tectonic and constructional misalignments in Peter Markli's gallery La Congiunta that amplify the heroic character of sculptor Hans Josephson's exhibited work (2010: 300-302); the symbolic, metaphorical and formal registers in Peter Zumthor's Sumvigt Chapel that conjugate into a 
considerable semantic texture (2010: $126-130)^{4}$ and the geometrical incommensurabilities in the spatial setup of Sigurd Lewerentz' St Peters that engage with the tragic dimensions of Christian theology (2010: 305-309); as well as in cinema - for example the multiple coincident temporalities in Nicholas Roeg's Bad Timing that challenge accepted notions of causality (2010: 70-71, 153-155); the narrative, material and geometrical layers in Sergei Paradjanov's Sayat Nova that translate the film into an iconostasis (2010: 101-103) and the distinctive image and sound juxtapositions of Werner Herzog's Lessons of Darkness that evoke an altered existential milieu, an ekstasis that enables the film to depict the hubris of human excess (2010: 175-176).

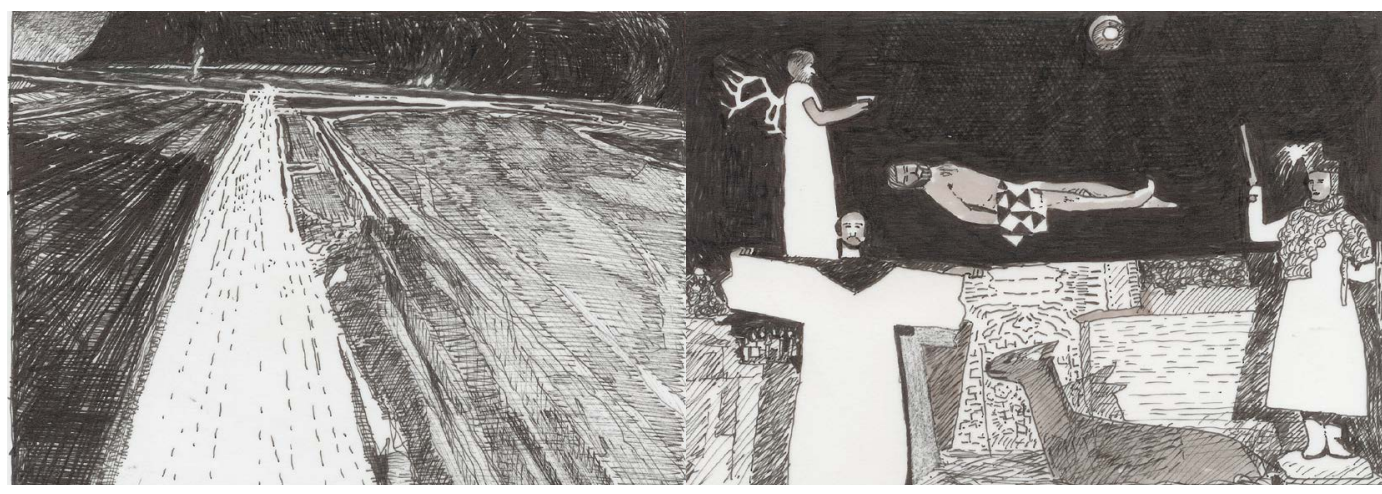

Fig. 19 Sergei Paradjanov (1968). Sayat nova. [Film still drawing: Author, 2009.]

Fig. 20 Werner Herzog (1992). Lessons of darkness. [Film still drawing: Author, 2010.]

In his call for scenography (phantastike techne) as a new paradigm for generating atmosphere, Gernot Böhme implies that architectural and urban settings, alongside the staging of politics, operas, sporting events and commodities, are essentially a matter of skenographia or mise-en-scène (2008: 4, 6). Peter Zumthor says as much when referring to the "art of seduction ... within the powers of an architect" that hinge on finding "a way of bringing separate parts of the building together so that they formed their own attachments, as it were" (2006: 43). Without doubt, in the instances cited above, architecture does construct symbolic, sociocultural and physical environments or conditions that can evoke moods, trigger reactions, promote engagements, convey meanings, prompt the recollection of memories and so forth. Architecture is theatrical, operatic and performative in that sense. But is the import of architectural settings thereby reducible to apparatuses for theatricality and conjured-up spectacle? Beyond its skenographic register, might atmosphere be deliverable through the consolidated material assemblage of architecture - its inherent geometric and formal structures, its spatiotemporal patterns and dynamics, its existential concrete presence and capacity to frame, reveal and amplify the complexions of place in an enduring, constantly unfolding way?

In this regard, the etymology of skenographia is instructive. The word derives from Greek skene, curtain or tent - in the sense of something that casts a shadow. The etymons are *SKEU, to cover, conceal and *SKEI, to cut, divide, split. The list of cognates is extensive and builds exactly the kind of incommensurable assemblage that I suggest gives rise to an ambiance or atmosphere of wonder: shadow, shade, shed, shekina/mishkan (Hebrew tabernacle, pavilion) sky, scene, scenery, skiagraphy (to trace shadows), skiamachy (to fight with shadows), shine, sheen, sheer, rescind, scission, shear, scotia, scale, skull, shield, shell, skin, ship, skiff, skipper. Yet a semantic keynote does permeate this list, pivoting on related antinomical motifs of uncovering/covering, appearing/disappearing, lightening/darkening and separating/connecting. The process of scenography, integral to the symbolic (and magical) character of theatre at its origins ${ }^{5}$, is therefore charged with tracing and dramatizing the arrival and entry of the sacred - that is, the sequestered, the out-of-frame or off-screen - through a 'veil of existence', the skene, from darkness into light. What is most important to retain here is the condition of semantic deferral and play: a kind of inter-ludic transaction between the various, multiplying thematic associations implied by the idea. Scenography is only 
pragmatically about setting up tableaus geared to producing atmospheric effects. More significant is the way in which a scenographic (or cinematic, or architectonic) setup makes possible something like a delinquent practice of recuperation, recollection, return and reabsorption of meanings, together with their interminable transactions, transfers and transformations.

Keeping meaning virtual, provisional and in a state of unactualised potential, as I have suggested above, should not be taken to mean the setup is without accuracy and rigour, or that it is unsystematic in any way. The discrepancies, incommensurabilities and misalignments must be designed-into the assemblage so that they co-operate productively, so that they are afforded the capacity to produce emergent conditions. Otherwise, the discrepancies might become counter-productive, they might interfere with or cancel each other out. The organisation of incommensurabilities must therefore entertain a high level of rigour and precision based on a sustained process of predictive modelling of potential outcomes and a reiterative adjustment or tempering of the system. This quite different concept of design(ing) engages the interstices between different layers or registers in the system; it is interested in the capacity and productivity of the in-between, the potential of the milieu, rather than the lineaments, edges or forms that gather around it. Without such precision and rigour the outcomes are likely to be tangled, muddled and confused; and this is exactly the difficulty one encounters with the rhetoric of atmosphere in architecture. Either the discourse becomes snagged in an unfortunate and unproductive fog of allusion and enigmatic confabulation, or it serves to maintain a mystique of incontestability around the charismatic, even prophetic figure of the architect/philosopher.

In Atmospheres, Zumthor advances a kind of alchemical lexicon to describe the phenomenon of atmosphere: enchantment, emotion, mood, magic, feelings, touch, body, radiance, presence, beauty, seduction, sense of place, sublime, transcendental ... words left in suspense, uncrafted, open to whatever interpretation, their potential meanings wandering and uncontextualised: “I don't know how to describe it actually, but I'm sure you know what I mean." (2006: 53) On the other hand Zumthor's reading of what produces atmosphere in architecture does hinge on what he calls "craft and graft" (2006: 21); on a certain rigour to do with the transactional and 'reactional' potential of adjacency in the combination of different materials for example; their tendencies to form "their own attachments" (43). This implies a science with distinctive tectonic strategies and tactics, a framework and practice of precision in the understanding and assemblage of component parts, together with their capacity to be, in different ways, in isolation and in conjugation: a systematic architectonics of atmosphere. Yet the shape and contents of this framework are not explicitly articulated. They remain latent and dissimulated in the artisan's innate and silent (hence unchallengeable) practice. What we lack therefore is an anatomy of atmosphere; an inventory, codification or classification of atmospheres aesthetic, certainly, but also metaphysical, political, religious, ethical, communitarian, theoretical, literary, musicological, spatial, temporal, theatrical, performative, environmental, climatic, civic, technological, computational, and so forth. This important work remains to be done, and must be done to avoid the concept of atmosphere in architecture remaining yet another unproductive trope; a mere figure of speech or turn of phrase whose dissimulated political function is to maintain the status quo of the architect as demiurge or magus, and of architectural design as unaccountably mysterious and hence subject to disciplinary power and control. As the ambiance of unrequitable desire is delivered by the precise musical structure, modal affordances and harmonic narrative of Mozart's F minor aria, in the final analysis atmosphere can only be delivered by the extance of architecture that is, its concrete materiality and presence, its affective spatiality and temporality and its capacity to move us into the unforeclosed and the unforeseen. 


\section{References}

Agamben, G. (1993). The coming community (M. Hardt, Trans.). Minneapolis, MA: The University of Minnesota Press. Agamben, G. (2011). Nudities (D. Kishik, S. Pedatella, Trans.). Stanford, CA: Stanford University.

Benjamin, W. (1992). The work of art in the age of mechanical reproduction. In Illuminations (H. Zohn, Trans.) 211-244. London, UK: Fontana Press.

Berque, A. (2000) Médiance, de milieu en paysages. Paris, France: Berlin/RECLUS.

Böhme, G. (1993). Atmosphere as the fundamental concept of a new aesthetics. Thesis Eleven 1993, 36. Retrieved from http://desteceres.com/boehme.pdf

Böhme, G. (1995). Atmosphäre: Essays zur neuen Ästhetik. Frankfurt am Main, Germany: Suhrkamp.

Böhme, G. (2005). Atmosphere as the subject matter of architecture. In P. Ursprung (Ed.), Herzog and de Meuron: Natural Histories (pp. 398-406). Montreal, Canada: Canadian Centre for Architecture and Lars Mueller Publishers.

Böhme, G. (2010). On beauty. The Nordic Journal of Aesthetics, 39, 22-33.

Böhme, G. (2012). Invasive technification. Critical essays in the philosophy of technology (C. Shingleton, Trans.). London, UK: Bloomsbury Publishing Plc.

Böhme, G. (2013) The art of the stage set as a paradigm for an aesthetics of atmospheres. Retrieved from http:// ambiances.revues.org/315

Delanda, M. (2006). A new philosophy of society: Assemblage theory and social complexity. London, UK, \& New York, NY: Continuum.

Delanda, M. (2012) Emergence, causality and realism. Architectural Theory Review, 17:1, 3-16.

Derrida, J. (2005). On touching - Jean-Luc Nancy (C. Irizarry, Trans.). Stanford, CA: Stanford University Press.

Deleuze, G. and Parnet, C. (2004). L'Abecedaire de Gilles Deleuze (DVD). Paris, France: Editions Montparnasse.

Deleuze, G. and Parnet, C. (1996) Dialogues. Paris, France: Flammarion.

Gaudin, H. (1992). Seuil et d'ailleurs. Paris, France: Les Editions du Demi Cercle.

Goetz, B. (2011), Oikos et poros. In Théorie des maisons. L'habitation, la surprise. Paris, France: Édition Verdier.

Harper, D. (2001-2014). Online etymological dictionary. Retrieved from http://www.etymonline.com

Heidegger, M. (1962). Being and time (J. Macquarrie and E. Robinson, Trans.). Oxford, UK: Basil Blackwell.

Heidegger, M. (1982). The basic problems of phenomenology (A. Hofstadter, Trans.). Bloomington, IN: Indiana University Press.

Heidegger, M. (1992). Parmenides (A. Schuwer and R. Rojcewicz, Trans.). Bloomington \& Indianapolis, IN: Indiana University Press.

Heidegger, M. (1994). Basic questions of philosophy. Selected "Problems" of "Logic" (R. Rojcewicz and A. Schuwer, Trans.). Bloomington \& Indianapolis, IN: Indiana University Press.

Hesse, M. (1965). Aristotle's logic of analogy. The Philosophical Quarterly, 15:61, 338.

Jullien, F. (2009). The great image has no form, or On the nonobject through painting (J-M. Todd, Trans.). Chicago, IL: University of Chicago Press.

Latour, B. (2003). Atmosphère, atmosphere. In S. May (Ed.), Olafur Eliasson: The weather project (29-42). London, UK: Tate Modern Publishing.

Ratcliffe, M. (2012). Why mood matters. Retrieved from http://philosophyofdepression.files.wordpress.com/2012/02/ heidegger-on-mood23rdsep2010.pdf

Sloterdijk, P. (2011). Bubbles:spheres, volume l: Microspherology (W. Hoban, Trans.). New York, NY: Semiotext(e). Stiegler, B. (2008). Prendre soin. De la jeunesse et des générations, Paris, France: Flammarion.

Tawa, M. (2010). Agencies of the frame. Tectonic strategies in cinema and architecture. Newcastle upon Tyne, UK: Cambridge Scholars Publishing.

Tawa, M. (2011). Theorising the project. A thematic approach to architectural design. Newcastle upon Tyne, UK: Cambridge Scholars Publishing.

Wilkins, J. (1638). Discovery of a new world or, discourse tending to prove that is probable there may be another habitable world in the Moon. London, UK: John Gillibrand.

Zumthor, P. (2006) Atmospheres: Architectural environments, surrounding objects. Berlin, Germany: Birkhauser. 


\section{Endnotes}

1. Madrepore means literally mother of pores. It is a genus of stony coral from the family Scleractinia that takes on labyrinthine, folded and porous forms. See B. Goetz (2011), 113-136.

2. The lyrics are as follows: L'ho perduta, me meschina! A h chi sa dove sarà? Non la trovo. L'ho perduta. Meschinella! E mia cugina? E il padron cosa dirà? (I have lost it, woe is me! Ah, who knows where it is? I can't find it. I have lost it. Miserable little me. And my cousin? And the boss, what will he say?)

3. I am indebted to my counterparts at the Sydney Conservatorium of Music, David Larkin and Lewis Cornwell, who generously provided the musicological detail in what follows.

4. Elsewhere, I have shown how multiple thematic references may be identified and used to build complex investigations of architectural precedents and frameworks for design. See Tawa (2011:149-207).

5. Theatre is from Greek théa, a seeing, spectacle, appearance, and -tron, a place, also an agential, instrumental suffix. Théa is cognate with theos, god - Latin deus, Greek Zeus, Sanskrit, deva. The common etymon is *DYEU, to gleam, shine; which also gives the root of words for sky and day - e.g. Latin dies, Sanscrit diva, day, diurnal. At its origins, theatre dramatises (effects, produces, conjures-up) the (luminous/ tenebrous) appearance and disappearance of the gods, the 'shining ones', for the staging of which an entire machinic apparatus had eventually to be invented. Heidegger's reading of alétheia (veracity/truth as 'un-concealment') and its counter (fallacy as 'forgetting', aligned with léthé, concealment, 'lethargy') is revealing philosophically - theatre shows the unconcealment (alétheia) and sighting (théa) of the god (theos) from covert latency (léthé) - but more so in the kind of tectonic investigations that privilege something like a mythologised antinomy between light and dark evident in both Zumthor's architecture and Böhme's scenographic metaphor. See Heidegger (1992): 17-39. 